\title{
The Prevalence of Hepatitis B Virus in High Risk Groups in Nineveh Governorate / Iraq
}

\author{
Rasha.W.Salim*
}

\author{
Basima A. Abdullah*
}

\author{
Received 20, December, 2012 \\ Accepted 3, March, 2014
}

\begin{abstract}
:
Hepatitis B is an inflammation of the liver that caused by Hepatitis B virus (HBV) which is DNA virus that infects the human and some kinds of animals such as chimpanzees and birds. This disease considered as the major disease of mankind and a serious global public health problem. $\mathrm{HBsAg}, \mathrm{HBeAg}, \mathrm{HBcAb}, \mathrm{HBeAb}$ and $\mathrm{HBsAb}$ are markers used to detect the presence and the stage of infection. The current study included (181) individuals from both sexes, (137) males and (44) females. By ratio 3.11: 1 . The mean age of patients $2.4033 \pm 0.83519$ (range 18-73) years as follows < $20(11.6 \%), 21-40(47.5 \%), 41-60(29.8 \%)$ and $>60(11.0 \%)$. These patients are 73 (40.4\%) Blood donors from Central Blood Bank, 88 (48.6\%) Chronic kidney failure at Ibn - Sina Teaching Hospital and $20(11.0 \%)$ Thalassemic patients at Ibn Alatheer Teaching Hospital, Nineveh Governorate / Iraq. For the period from July 2011 till May 2012.The results indicated that the number of serum patients infected with HBV was 90 (49.7\%) using Enzyme Linked Immuno Sorbent Assay technique. These patients had many markers named $\mathrm{HBsAg}, \mathrm{HBeAg}, \mathrm{HBcAb}, \mathrm{HBeAb}$ and HBsAb with percentages 90 (49.7\%), 47 (26.0\%), 89 (49.2\%), 53 (29.3\%) and5 $(2.8 \%)$ respectively. Ninety three patients infected with HBV ninety of them gave positive results using ELISA and rt-PCR technique, and three gave positive results using rt-PCR only inspite of their negative results in ELISA. We concluded that HBV infection remains a serious issue because it's prevalence is still significant among patients, all viral markers are very important for the diagnosis of infection, rt-PCR is a very sensitive scientific technique gave the exactly number of copies/ml in a closed system.
\end{abstract}

Key words: Hepatitis B, Liver function tests, Hepatitis B Virus markers, real time - PCR

\section{Introduction:}

Hepatitis $\mathrm{B}$ is a viral disease caused by Hepatitis B Virus (HBV). This disease considered as the major of disease and a serious global public health problem. HBV is endemic throughout the world and shed in blood and all body fluids by individuals with acute or chronic infections [1]. It's infection may lead to cirrhosis, hepatocellular carcinoma or death. $\mathrm{HBV}$ is DNA virus that infects the human and some kinds of animals such as chimpanzees and birds. More important, HBV infection is a global health problem. Two billion people have been infected worldwide; 360 million are chronically infected, over 520,000 die each year $(50,000$ of acute hepatitis B and 470,000 of cirrhosis or develop to hepatocellular carcinoma [2]. There are serological markers Hepatitis B surfaces antigen (HBsAg), Hepatitis B e antigen (HBeAg), Hepatitis B patients also contain circulating antibodies against Hepatitis *Department of Biology (Microbiology) College of Science /University of Mosul /Iraq 
and Hepatitis B surfaces antigen called Hepatitis B core antibody ( $\mathrm{HBcAb}$ ), Hepatitis B e antibody (HBeAb) and Hepatitis B surfaces antibody (HBsAb). Hepatitis B core antigen (HBcAg) was found only in hepatocytes and not found in blood stream. There are sequential appearance and disappearance of these five serological markers during atypical course of infection $[3,4,5]$. The first stage of infection is characterized by the presence of $\mathrm{HBsAg}, \mathrm{HBeAg}$ and IgM class of $\mathrm{HBcAb}$ and may last for decades in the intermediate stage. Patients lose $\mathrm{HBeAg}$ and develop to $\mathrm{HBeAb}$ and often enter in a clinical remission. Finally, the patient lose $\mathrm{HBsAg}$ and rises $\mathrm{HBsAb}$ which refer to the recovery stage from infection [6].Polymerase chain reaction (PCR) is a scientific technique in molecular biology used to amplify a single or few copies of DNA across several orders of magnitude for generating thousands to millions copies of a particular DNA sequences [5], but Real Time - PCR is a technique used for the qualitative and quantitative detection of DNA in samples by amplifying and simultaneously quantifying a targeted DNA molecule for one or more specific sequences in DNA sample [7]. We concluded that HBV infection remains a serious issue because it's prevalence is still significant among patients, all viral markers are very important for the diagnosis of infection rt-PCR is a very sensitive scientific technique gave the exactly number of copies/ml in a closed system.

\section{Materials and Methods:}

A total number of patients was (181) from both sexes, comprising (73) Blood donors from Central Blood Bank, (88) Chronic Kidney failure at Ibn -Sina Teaching Hospital, (20) Thalassemic patients at Ibn-Al atheer Teaching Hospital in Nineveh
Governorate, for the period from July 2011 till May 2012, their ages ranged from (18-73) years with mean of (2.40 $\pm 0.83)$ years. Sera were separated by centrifuge $(3000 \mathrm{rpm})$ and stored at $20^{\circ} \mathrm{C}$. Sera were tested to detect the presence of HBV using Micro ELISA Screening from (Plasmatec company ,UK). The Absorbance was measured at $450 \mathrm{~nm}$ by the reader, cut-off value equals 0.100 . The positive sample absorbance was greater than or equal to $\geq$ cutoff value but the negative samples absorbance was less than < cutoff value. Sera were also tested to determine the HBV markers $\mathrm{HBsAg}$, $\mathrm{HBeAg}, \mathrm{HBsAb}, \mathrm{HBcAb}$ and $\mathrm{HBeAb}$ by One step multi HBV test device consists of 5 chromatographic strips. Each strip detects a certain HBV marker in Immuno chromatography assay using specific kit from (Plasmatec company, UK). Sixty micro liter of serum samples or plasma was added to each well and simultaneously timing starts. The results were recorded after 15 minutes.Finally, sera were tested to determine the Quantitative detection of HBV by $\mathrm{rt}-\mathrm{PCR}$ technique using specific kit from (Analitik Jena, Germany) for DNA Extraction step and another specific kit from (Primer Design, USA) for amplification step .

\section{Results and Discussion:}

Recently, HBV infection has truly become a problem which we still face. In Nineveh city, the number of patients has become noticeably medium. Worth noting is that all cases were detected accidently during blood transfusion or other undirected tests, noticeably at Oncology unit, Hemodialysis unit, Central blood bank and Public health laboratory in Nineveh governorate. The number of blood donors were $7998.72(0.90 \%)$ of them were infected with $\mathrm{HBV}$ and five infected with HCV. A total number of 
patients in chronic kidney failure was $130,17(13.0 \%)$ of them were infected with HBV and 25 (19.2\%) infected with HCV. All of them were negative for HIV. Table -1- Showed the number of serum samples which investigated in our study, the results indicated that 90 (49.7\%) gave positive and 91(50.3\%) gave negative result for $\mathrm{HBV}$ using ELISA technique.

Table -1- Percentage of serum samples infected and non infected with HBV using ELISA technique

\begin{tabular}{|l|l|l|}
\hline Serum samples & $\begin{array}{l}\text { Infected with } \\
\text { HBV(No.\%) }\end{array}$ & $\begin{array}{l}\text { Noninfected } \\
\text { with HBV } \\
\text { (No.\%) }\end{array}$ \\
\hline Blood donors & $72(39.77)$ & $1(0.55)$ \\
\hline Hemodialysis & $17(9.39)$ & $71(93.22)$ \\
\hline Thalassemia & $1(0.55)$ & $19(10.42)$ \\
\hline Total & $90(49.7)$ & $91(50.3)$ \\
\hline
\end{tabular}

This study agree with other studies carried out worldwide such as, McMahon [9] who showed that the prevalence of chronic HBV infection worldwide could be categorized as high, medium and low endemicity. HBV is moderately endemic in parts of eastern and southern Europe, middle east and south America. Between (10$60 \%$ ) of the population have evidence of infection, and (2-7\%) as chronic carriers [8].

Alter [10] who showed that HBV infection prevalence varies markedly in different geographic areas of the world as well as indifferent population subgroups. It ranged over $10 \%$ in some Asian and Western Pacific countries to under $0.5 \%$ in the United States and Northern European countries. The patients who gave positive results for HBV must be tested to detect the presence of $\mathrm{HBV}$ markers to identify and know the stage of HBV infection, these markers are $\mathrm{HBsAg}, \mathrm{HBsAb}$, $\mathrm{HBeAg}, \mathrm{HBeAb}$ and $\mathrm{HBcAb}$. The result of all these markers as illustrated in Table -2 -
Table -2- Percentages of the prevalence of $\mathrm{HBV}$ markers using Immuno chromatography assay.

\begin{tabular}{|r|r|r|r|r|}
\hline Markers & $\begin{array}{r}\text { Positive } \\
\text { No. (\%) }\end{array}$ & $\begin{array}{r}\text { Negative } \\
\text { No. (\%) }\end{array}$ & $\begin{array}{r}\text { Non } \\
\text { infection } \\
\text { No. (\%) }\end{array}$ & $\begin{array}{r}\text { Mean } \pm \\
\text { SD }\end{array}$ \\
\hline $\mathrm{HBsAg}$ & $90(49.7)$ & $5(2.8)$ & $86(47.5)$ & $2.87 \pm 2.03$ \\
\hline $\mathrm{HBeAg}$ & $47(26.0)$ & $48(26.5)$ & $86(47.5)$ & $2.64 \pm 2.28$ \\
\hline $\mathrm{HBcAb}$ & $89(49.2)$ & $6(3.3)$ & $86(47.5)$ & $2.87 \pm 2.04$ \\
\hline $\mathrm{HBeAb}$ & $53(29.3)$ & $42(23.2)$ & $86(47.5)$ & $2.61 \pm 2.31$ \\
\hline $\mathrm{HBsAb}$ & $5(2.8)$ & $90(49.7)$ & $86(47.5)$ & $2.38 \pm 2.50$ \\
\hline $\mathrm{Total}$ & \multicolumn{4}{|c}{$181(100.0)$} \\
\hline
\end{tabular}

The numbers of patients who gave positive and negative results for HBsAg marker are 90 (49.7\%) and 5 $(2.8 \%)$ respectively, non infection were $86(47.5 \%)$ with the mean $2.87 \pm 2.03$ who don't have the infection with HBV. The result of this study is similar to other studies conducted in Basrah, Iraq such as Al- Hmudi [11] who showed that $44.52 \%$ had HBsAg marker. Weber et al.[12] who showed that HBsAg may turn negative in the early stage of the disease course but in chronic HBV infections patients, this marker can be persistently positive. $\mathrm{HBeAg}$ is considered as a better marker of viral blood infection that comes from a core of HBV. When HBV core degrades in the serum, this antigen is created and can be detected, because $\mathrm{HBcAg}$ will be totally degraded in the serum. When $\mathrm{HBeAg}$ marker becomes positive, it is equivalent to positive $\mathrm{HBcAg}$ marker and shows that $\mathrm{HBV}$ is replicating actively in hepatocyte and the patient is infectious $[13,14]$. HBeAb is the body's immune reaction to $\mathrm{HBeAg}$ and combines with it. It usually appeared after $\mathrm{HBeAg}$ turns to negative; which also means that HBV replication activities have decreased and the patient becomes non infectious at all. The development of host Antibodies to $\mathrm{HBeAg}$ indicated the assessment of immunity and reduction viral replication in infected individuals [15].The current study indicated that the numbers of patients who gave positive results for $\mathrm{HBeAg}$ were 47 
(26.0\%), negative $48(26.5 \%)$ and non infection $86(47.5 \%)$ with the mean $2.64 \pm 2.28$, while for $\mathrm{HBeAb}$ were $53(29.3 \%)$, negative $42(23.2 \%)$ and non infection $86(47.5 \%)$ with the mean $2.61 \pm 2.31$.On comparing this study with other studies done in Iraq, Al Jaaf [16] who showed that the prevalence of $\mathrm{HBeAg}$ and $\mathrm{HBeAb}$ among chronic group were $(36 \%, 58 \%)$ respectively but among the carrier group were $(2 \%, 94 \%)$ respectively. Youssif [17] who found that $54.2 \%$ had HBeAg marker and $44.58 \%$ had $\mathrm{HBeAb}$ marker. Other studies done in Iraq showed that a higher prevalence of HBeAg among carrier group, namely Omar and $\mathrm{Al}$ - Douri [18] who found that $25 \%$ of $\mathrm{HBsAg}$ positive female nursery staff were $\mathrm{HBeAg}$ positive and $43 \%$ positive for $\mathrm{HBeAb}$. $\mathrm{HBcAg}$ is not commercially available because it is not found in the serum. Therefore, we cannot find it. But it is available in hepatocyte only. $\mathrm{HBcAb}$ is available in serum only and its presence may refer to the replication of HBV in hepatocyte [19]. The current study indicate that the number of patients who gave positive results for $\mathrm{HBcAb}$ were 89 $(49.2 \%)$, negative $6(3.3 \%)$ and noninfection $86(47.5 \%)$ with the mean $2.87 \pm 2.04$, and the number of patients who gave positive results for $\mathrm{HBsAb}$ were $5(2.8 \%)$, negative $90(23.2 \%)$, non-infection $86(47.5 \%)$ with the mean $2.38 \pm 2.50$. This study agree with other studies done in the world such as[20] who showed that HBsAb is an immunoglobulin secreted by Plasma cells that can combine with HBsAg to neutralize it. A long with other immune reactions, $\mathrm{HBsAb}$ can eradicate the invading $\mathrm{HBV}$ from the body. Either HBV vaccinations can cause HBsAb marker to be positive. This antibody can exit in the blood for a long time and gradually decreases with age. The patients who gave positive results for $\mathrm{HBsAb}$ and negative for $\mathrm{HBsAg}$ must be tested in molecular ways such as real - time PCR to know if the patients enter in recovery phase and $\mathrm{HBsAg}$ level declined or disappeared from the serum. The results indicated that three of them HBsAg level were very low (less than cutoff +0.100 ) therefore, not detected using ELISA technique but detected using rt- PCR and two are not detected using both of them. Therefore, we have to use rt- PCR technique to give the exactly number of particles $/ \mathrm{ml}$ of blood and confirm the infection with HBV especially in some patients suspected by the infection. So, the results indicated that ninety three patients infected with HBV ninety of them gave positive results using ELISA and rt- PCR and three gave positive results using rt- PCR only inspite of their negative results in ELISA technique. Table -3- Explain the results clearly.

Table -3- Percentage of serum samples who gave positive and negative results using ELISA and rtPCR techniques.

\begin{tabular}{|c|c|c|}
\hline $\begin{array}{c}\text { Serum } \\
\text { samples }\end{array}$ & $\begin{array}{c}\text { ELISA } \\
\text { technique No. } \\
(\%)\end{array}$ & $\begin{array}{c}\text { Real time- } \\
\text { PCR No. } \\
(\%)\end{array}$ \\
\hline HBV positive & $90(49.7)$ & $93(51.4)$ \\
\hline HBV negative & $91(50.3)$ & $88(48.6)$ \\
\hline Total & \multicolumn{2}{|c|}{$181(100.0)$} \\
\hline
\end{tabular}

Enzyme Linked Immuno Sorbent Assay technique depend on the presence of HBsAg in the serum samples, if HBsAg level was high at that time gave positive results but, if HBsAg level was very low at that time gave negative results therefore, we used rt-PCR which is very sensitive technique and can detect few numbers of particles $/ \mathrm{ml}$. 


\section{References:}

[1] Lin, HH and Wang, LY.(2005). Vaccination for hepatitis B. Tzu. Chi. Med. J. 17 (5): 303 - 309.

[2] WGO.(2008). Hepatitis B. World Gastroenterology Organization Practice Guideline: 1-25.

[3] Magnius, L and Espamark, J .(1972). New specificities in Australian Antigen positive sera distinct from the le Bouvier determinants. J. Immunol. 109: 1017 - 1021.

[4] Beasley, R; Hwang, L; Lin,C and Chien, C.(1981). Hepatocellular carcinoma and hepatitis B virus. Lancet. 2: $1129-1133$.

[5] Bartlett, J M and Stirling, D.(2003). A short history of the polymerase chain reaction. PCR protocols. 226 (10): 3-6.

[6] Tong, SH; Kim, KH; Chante, CH; Wands, J and Li, J.(2011). Hepatitis B virus e antigen variants. Int. J. Med. Sci. 2 (1): 2-7.

[7] Udvardi, MK; Czechoweski, T and Scheible, WR.(2008). Eleven golden rules of quantitative RT-PCR. Plant Cell. 20 (7): 1736 - 1737.

[8] Center for Disease Control and Prevention.(2005). Interpretation of hepatitis B serological test results. MMWR. 54 (11): RR-16.

[9] McMahon, BJ.(2005). Epidemiology and natural history of hepatitis B. Semin Liver Dis.25:3-8. [10] Alter, MJ.(2003). Epidemiology and prevention of hepatitis B. Semin Liver Dis. 23:39-46.

AL-Hmudi, AH.(2011).Virological and immuno genetic study of hepatitis B virus in patients of Basrah Province - Iraq. Ph.D thesis in Microbiology. College of Science. University of Basrah.
[12] Weber, B; Melchior, W; Gehrke, R; Doerr, HW; Berger, A and Rabenau, H.(2001). Hepatitis B virus marker in anti $\mathrm{HBc}$ only positive individuals. J. Med. Virol. 64: 309312.

[13] Perrillo, R; Richman, D and Sherman, K.(2009). Pocket guide to hepatitis B. University of Wisconsin Board of reagents and MDG Development Group 1-63.

[14] Bihla, F; Alaeia, M and Negroa, F.(2010). The new EASL guidelines for the management of hepatitis B infection adapted for Swiss physician. Swiss Med. Wkly.140 (11 - 12): 154 159.

[15] Sablon, E and Shapiro, F.(2005). Advances in molecular diagnosis of HBV infection and drug resistance. Int. J. Med. Sci.2: 8-16.

[16] AL-Jaaf, AM.(2006). A study of hepatitis B virus precore mutant among Iraqi chronic hepatitis B patients treated with interferon Alfa. Msc. thesis. Council of Genetic Engineering and Biotechnology Institute. University of Baghdad.

[17] Youssif, T.(1998).Immunological study of patients with chronic active hepatitis B. Ph.D. thesis, College of Medicine. University of Baghdad.

[18] Omer, A and AL-Douri, S.(1984).Viral hepatitis in Iraqi normal population. proceeding of the $6^{\text {th }}$ international congress of Virology, Sendai - Japan; 32 - 36.

[19] Kumar, V; Das, S and Jameel, S.(2010).The biology and pathogenesis of hepatitis viruses. Current science. 98 (3): 312-325.

[20] Lavanchy, D.(2004).Hepatitis B virus epidemiology, disease burden, treatment and Current and emerging prevention and control measures. J. Viral. Hepatol.11: 97-107. 


\section{أنتشار التهاب الكبد الفيروسي نمط B لاى المجاميع عالية الخطورة في محافظة

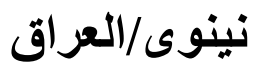

باسعة /حمد عبد/الله*

$$
\text { رشا وصفي سالم }
$$

* كلية العلوم / قسم علوم الحياة / احياء مجهرية/ جامعة الموصل / العراق

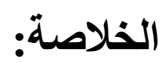

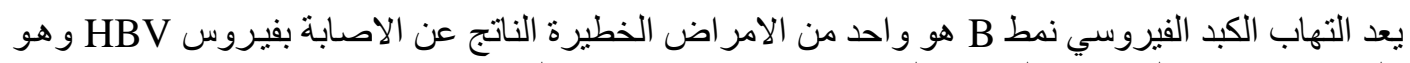

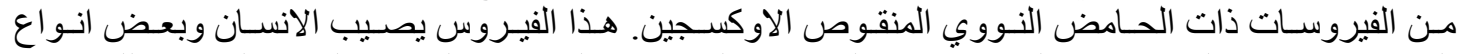

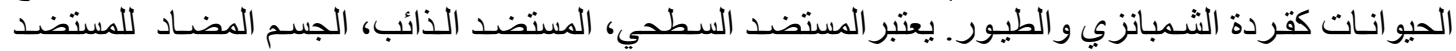

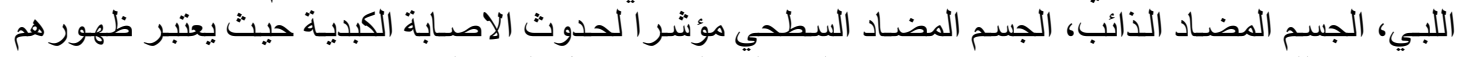

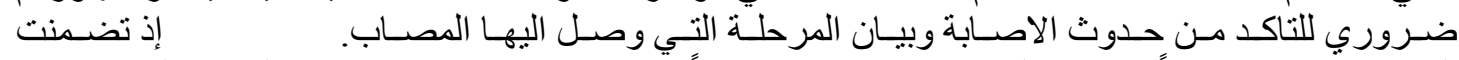

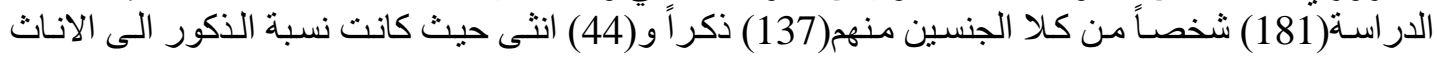

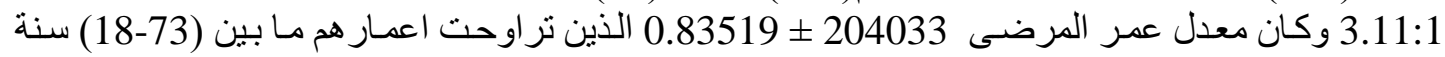

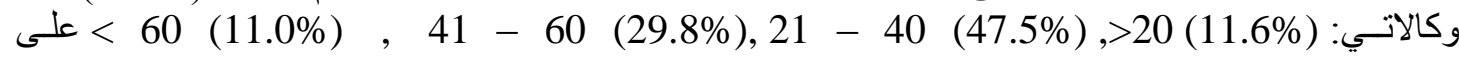

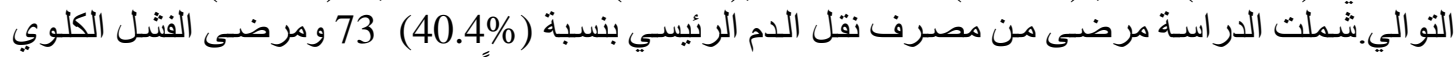

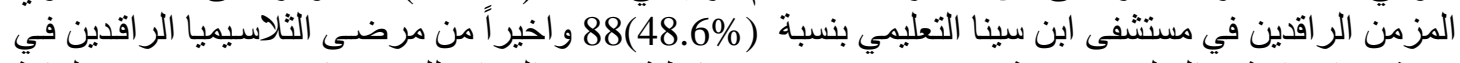

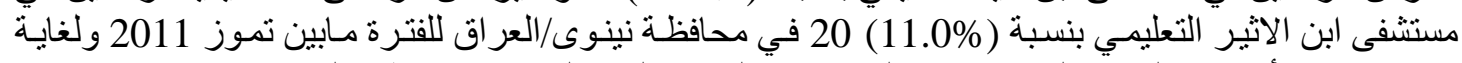

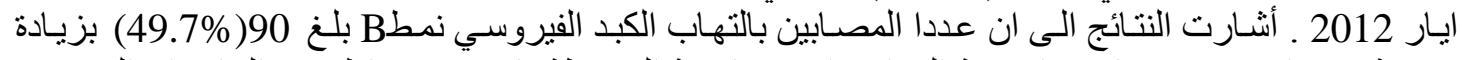

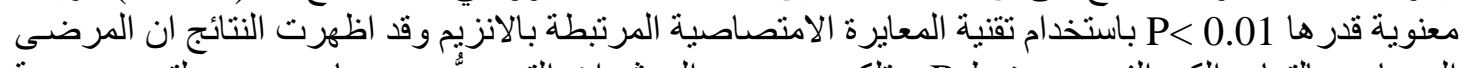

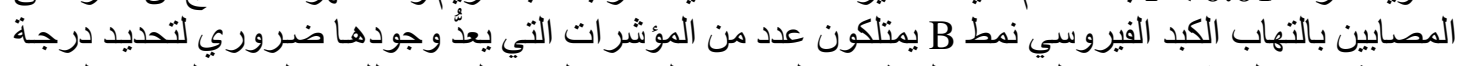

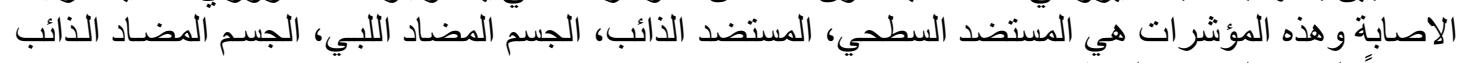

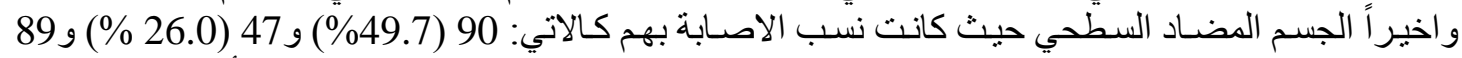

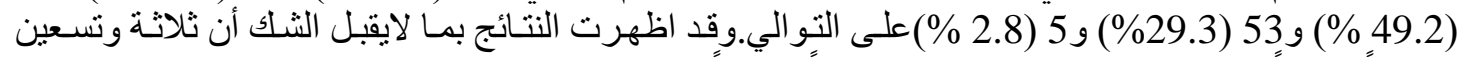

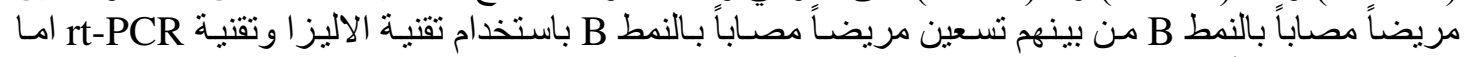

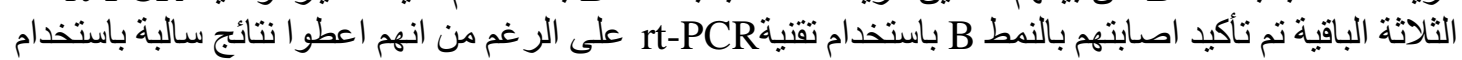

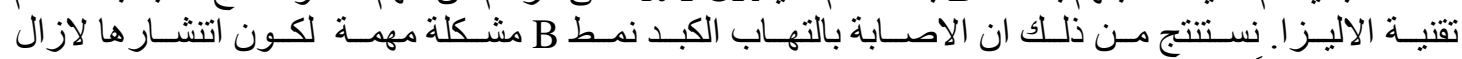

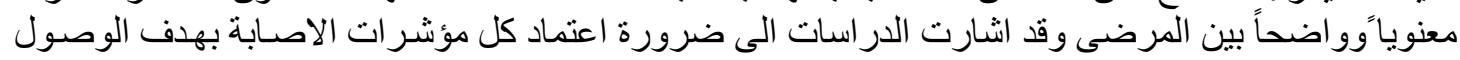

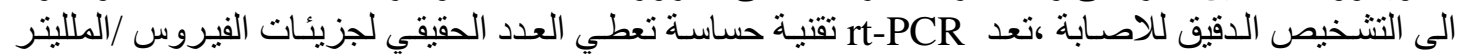
الو احد من الدم ضمن نظام مغلق. 